\title{
DETERMINATION OF OPTIMAL EXTRACTION CONDITIONS OF PHENOLIC COMPOUNDS FROM ACORUS CALAMUS LEAVES
}

\author{
Maksym Yaremenko \\ Department of botany ${ }^{1}$ \\ Tetiana Gontova \\ Department of botany \\ Liudmyla Boryak \\ Department of organic chemistry ${ }^{1}$ \\ Olga Mala \\ Department of botany ${ }^{1}$ \\ Oleksiy Andryushayev \\ Department of Industrial Technology of Drugs ${ }^{1}$ \\ ${ }^{1}$ National University of Pharmacy \\ 53 Pushkinska str., Kharkiv, Ukraine, 61002
}

\begin{abstract}
From the beginning of its existence and until now, interest in herbal remedies has only grown. Not surprisingly, medicinal herbs are a source of unique combinations of biologically active components that are capable of exhibiting significant pharmacological effects. One of these medicinal plants is Acorus calamus (sweet flag), whose rhizomes have long been used in official and folk medicine, cooking and cosmetology. However, recent studies point to the considerable potential of the aerial part of Acorus calamus as a novel herbal remedy, which is associated with the presence in the leaf of the plant, in addition to essential oil, a considerable amount of substances of phenolic nature.

The aim of the research was to determine the optimal conditions for the removal of phenolic compounds from the leaves of Acorus calamus and to determine the technological parameters of raw materials.

Materials and methods. During the research, samples of raw materials collected on the territory of Kharkiv region were used, as well as methods that are given in the State Pharmacopoeia of Ukraine.

Result. As a result of the research, the extraction conditions at which there was highest content of the extraction of biologically active substances were determined. The extractant, the degree of grinding of the raw material and the optimum extraction time were selected, which allowed to extract almost $80 \%$ of the quantitative content of flavonoids from the raw material. The main technological parameters of Acorus calamus leaves were also determined. The obtained results will be the basis for the development of the technology of obtaining phyto-substance from the leaves of Acorus calamus.

Conclusions. The selection of optimal extraction conditions of biologically active compounds from Acorus calamus leaves was carried out. The obtained results show that in order to obtain extracts with the maximum content of biologically active substances (flavonoids), it is advisable to use raw materials with a particle size of 0.5 to $1.0 \mathrm{~mm}$, as an extractant $70 \%$ alcohol and an extraction time of 4 hours.
\end{abstract}

Keywords: Acorus calamus, leaves, extraction, standardization.

DOI: $10.21303 / 2504-5679.2020 .001317$

\section{Introduction}

Medicinal herbal remedies have always been very popular. Since ancient times and until now the relevance of plant research is only increasing. The use of herbal remedies and phytonutrients has continued to increase throughout the world, both in developed and developing countries [1]. It is in countries that do not have a modern healthcare system that on herbal and traditional medicines relies population in the treatment and prevention of diseases. 
Such interest is completely understandable, because plants are an essential source of naturally occurring biologically active compounds such as flavonoids, essential oils, alkaloids, carotenoids, vitamins, carboxylic acids, and others. Phenolic compounds are one of the most important plant metabolites. These compounds are involved in the regulation of seed germination and cooperate in the regulation of plant growth, and are involved in protective reactions during infection, excessive sun exposure, trauma and stress. Polyphenols play an important role in photosynthesis, respiration, plant growth, fruit and vegetable resistance to infectious diseases. They depend on the colour, aroma, taste, darkening of the tissues of the fruits and their P-vitamin value [2]. In addition, herbal phenol derivatives exhibit a considerable range of pharmacological activity, exhibiting anti-inflammatory, antioxidant, antimicrobial, analgesic, antipyretic, antitumor activity, etc. [3].

Each type of plant accumulates in its composition a unique set of biologically active substances (BAS), which causes such different pharmacological action of herbal remedies based on them. A thorough study of the chemical composition and the selection of optimal extraction conditions will allow the most effective use of the medicinal potential contained in the plant. One of the plants with extremely high potential is the sweet flag or calamus (Acorus calamus L.). The rhizome of the plant has been used for thousands of years in both folk and official medicine, as well as in cosmetology and the food industry. Only in the territory of Ukraine about 20 medicines, which include rhizome Acorus calamus, have been registered [4]. These drugs are used to treat diseases of the gastrointestinal tract such as gastritis with low and high acidity, diarrhoea, peptic ulcer and others.

Rootstalks of Acorus calamus - ether-containing raw material. The content of essential oil varies depending on the type. Thus, in diploid plants an average of $2.2 \%$ of essential oil is contained, in triploid $-3.1 \%$, in tetraploid $-6.8 \%$ [5]. It consists of a number of monoterpenes $\alpha$ - and $\beta$-pinene, para-cymene, $\alpha$-terpinene, $\gamma$-terpinene, $\beta$-phellandrene, terpinolen, limonene, D-camphene, D-camphor, borneol, calarene. The available compounds of the sesquiterpene series are shyobunone, epishyobunol, isocalamendiol, calamene, curcumin, guinea, caryophyllene, isoacorone. The specific odour of the essential oil is due to the presence of phenylpropane derivatives: azarylaldehyde and asarone $(\alpha, \beta)[6,7]$. The chemical composition of the roots of Acorus calamus, except for the essential oil is represented by flavone - galanin, lignin - acoradin. Also available is a steroid - $\beta$-sitosterol. [8]. Studies on the composition of fatty acids have shown the presence of myristic, palmitic, palmitoleic, stearic, oleic, linoleic, peanut acids [9].

Tannins are represented by catechin [6].

At the same time, the study of the composition of biologically active substances (BAS) of the leaves of Acorus calamus was practically not conducted. The review of domestic and foreign literature sources, as well as own studies of the qualitative composition and quantitative content of BAS leaves of Acorus calamus indicate the relevance of a more in-depth study of the possibilities of using this raw material in medicine. In particular, there are results of a study of the antioxidant activity of methanolic extracts of Acorus calamus leaves [10]. In addition, there are results of determination of anti-inflammatory activity of water extracts of Acorus calamus leaves [11]. Thus, according to the literature and our own research, it was found that the qualitative composition and quantitative content of essential oil components in Acorus calamus leaves and rhizomes are similar $[12,13]$. In addition, about $1 \%$ of flavonoids and hydroxycoric acids were found in Acorus calamus leaves [14].

In addition to its medicinal value, the use of the aboveground part will reduce the burden on the natural resources of Acorus calamus, especially in countries where wild raw materials are widely used, since harvesting Acorus calamus leaves has virtually no effect on plant viability, unlike rooting. Conservation of the plant population is a pressing issue in the territory of Ukraine, where the dynamics of calamus resources in the left-bank Ukraine forest steppe and steppe indicate that stocks are scarce, resources are diminished, and raw material harvesting must be strictly controlled [15]. 
All this gives reason to recommend the leaves of the plant as a promising raw material for the development of new drugs based on it.

The aim of the research was to select the optimal conditions for the extraction of phenolic compounds from the leaves of Acorus calamus and study the technological parameters of raw materials for further development of technology for obtaining phytosubstances with the maximum content of these groups' substances.

\section{Materials and methods}

The objects of study were water-alcohol extracts from the dried leaves of Acorus calamus. The aboveground part of the plant was harvested in the mass flowering phase, when the greatest amount of BAS accumulates, in the territory of Kharkiv region, Ukraine [16]. Drying of the raw materials was carried out by air-shadow method at temperatures of $30-35{ }^{\circ} \mathrm{C}$. Raw materials were used to determine the optimal extraction conditions and technological parameters, the qualitative composition and quantitative content of phenolic compounds were determined and published in our previous studies. The content of flavonoids in raw materials was $1.13 \%$ [16].

In determining the optimal conditions for the extraction of compounds of phenolic nature, we investigated how changing such parameters as the degree of grinding, the type of extractant and the time of extraction affect the extraction process [17].

Selection of the optimal extractant is one of the most important aspects of the development of technology for the preparation of medicinal herbs, since it depends on the nature and amount of BAS recovered, which will directly affect the biological activity of the phytopreparation [17]. Water P was used as the extractant, as well as aqueous solutions with different concentrations of ethanol, obtained by mixing the corresponding volumes of ethyl rectified alcohol and water $\mathrm{P}$. The concentration of the obtained solutions was additionally calculated from relative density using alcoholic tables of SPhU [18]. Extraction is carried out at a ratio of raw material-extractant 1:5.

The main task of the process of grinding raw materials - the maximum destruction of cellular structures in order to increase the contact surface of the extractant with the raw material, increase the rate of dissolution of BAS and simplify their exit from the cell. The degree of grinding of raw materials was determined in accordance with Article 2.9.12. "Sieve analysis" of the State Pharmacopoeia of Ukraine (SPhU) [18].

The completeness of BAS extraction was evaluated by two criteria: dry residue content and flavonoid content. The dry residue content in the samples of the extracts obtained was determined according to Article 2.8.16 of the SPHU [10]. The quantitative content of flavonoids in Acorus calamus leaf and the obtained extracts were investigated using the unified spectrophotometric method in terms of the hyperoside described in the SPhU "Hawthorn leaves and flower" monograph [19].

The determination and calculation of such technological parameters as specific gravity, porosis, porosity, free volume of the layer, specific surface area and particle size were performed according to the commonly used methods [20, 21].

The temperature directly affects the rate of dissolution and diffusion of the substance into the extractant. However, the rise in temperature has a negative effect on thermolabile and volatile substances.

The extraction was carried out by the method of percolation according to the following method: a sample of the raw material was placed in the percolator and filled with fresh extractant in the ratio of raw material-extractant 1:5. Then the tightly closed percolator was left for infusion. The extraction was performed at room temperature in a place protected from direct sunlight. After receipt of the extract, it was placed for 24 hours at $8^{\circ} \mathrm{C}$, then filtered through a paper filter "blue ribbon".

\section{Results}

In the first stage of the work, the content of flavonoid content and dry residue were determined depending on the type of extractant. Water and aqueous-alcoholic mixtures with an alcohol 
concentration of $30 \%, 50 \%, 70 \%$ and $96 \%$ were used as the extractants. The degree of grinding of raw materials was at the level of 3-5 mm. Extraction time is $30 \mathrm{~min}$. The results are presented at Fig. 1, 2.

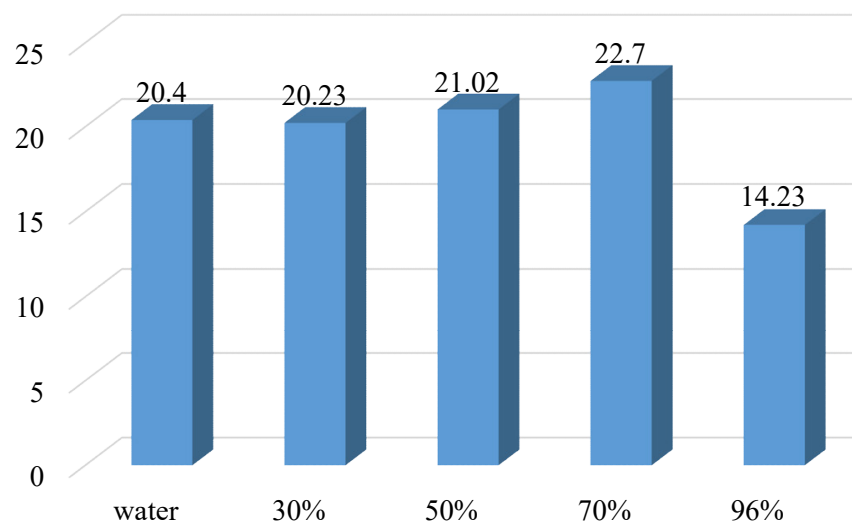

Fig. 1. Dry residue extracts when using different types of extractant, in percent

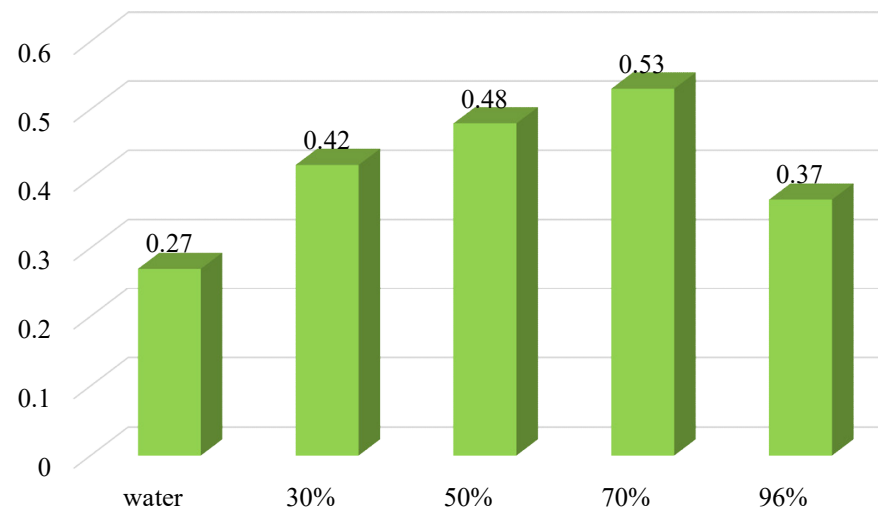

Fig. 2. The content of the amount of flavonoids extracts when using different types of extractant, in percentage

According to the data obtained, the preferred extractant was $70 \%$ ethanol.

In the second stage of the study, the effect of grinding of raw materials on the extraction of biologically active substances was investigated. The extractant is $70 \%$ ethanol.

Extraction time is $30 \mathrm{~min}$. The obtained results are presented in Fig. 3, 4.

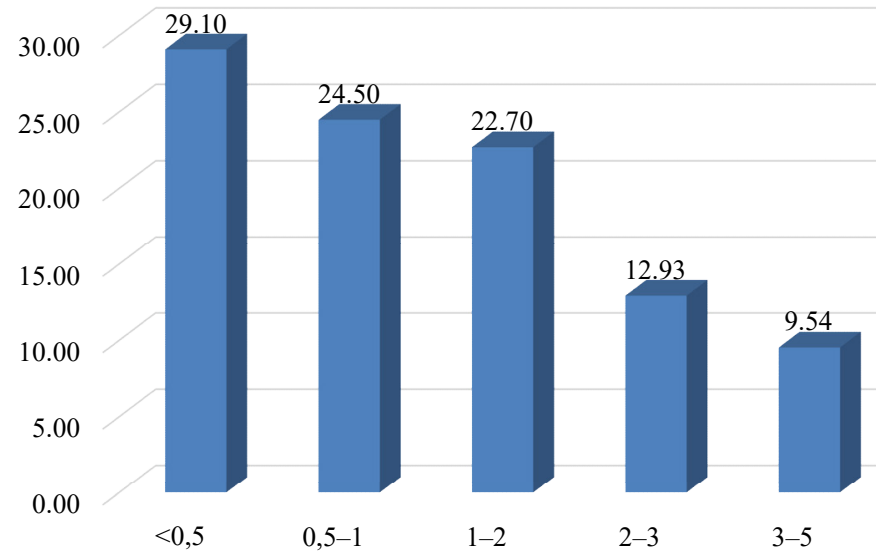

Fig. 3. Dry residue of extracts obtained from raw materials of various sizes, in percent 
According to the obtained data, the degree of extraction of extractives and compounds of phenolic nature increases as the size of the raw material particles decreases. Raw materials with dimensions less than $0.5 \mathrm{~mm}$ have the highest value of quantitative content of flavonoids amount $0.81 \%$, as well as the highest content of dry residue $-29.10 \%$. However, the use of raw materials smaller than $0.5 \mathrm{~mm}$ is accompanied by a number of technological problems. First, due to the high density of the raw material when stacked, its wettability in the inner and lower layers deteriorates. Secondly, in addition to biologically active substances, ballasts and particles of raw materials are significantly extracted from the raw material. This necessitates additional cleaning of the extract. Therefore, in our opinion, it is optimal to use raw material with a particle size of 0.5 to $1.0 \mathrm{~mm}$.

In determining the optimum extraction time of biologically active substances, $70 \%$ ethanol and raw materials with a grinding rate of 0.5 to $1.0 \mathrm{~mm}$ were used as the extractant. The following time intervals were used for the study: 30 minutes, 1 hour, 2 hours, 4 and 8 hours. The results are presented in Fig. 5.

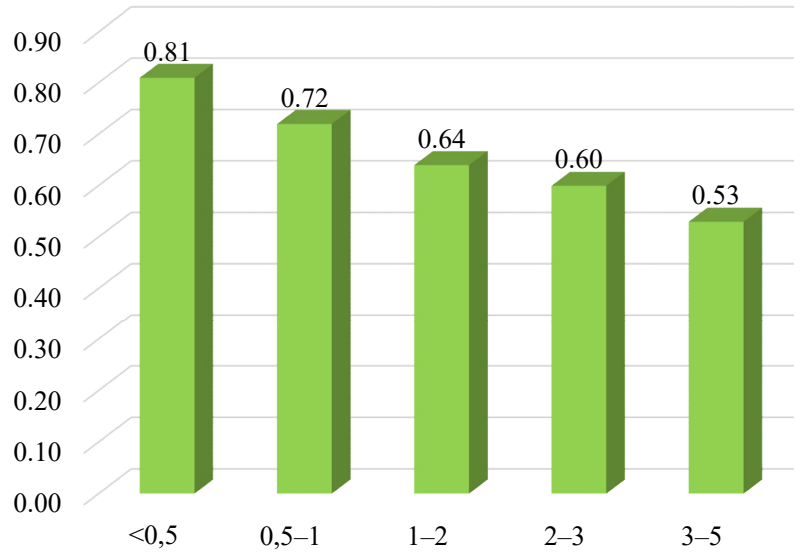

Fig. 4. The content of flavonoids amount of extracts obtained from raw materials of different sizes, in percent

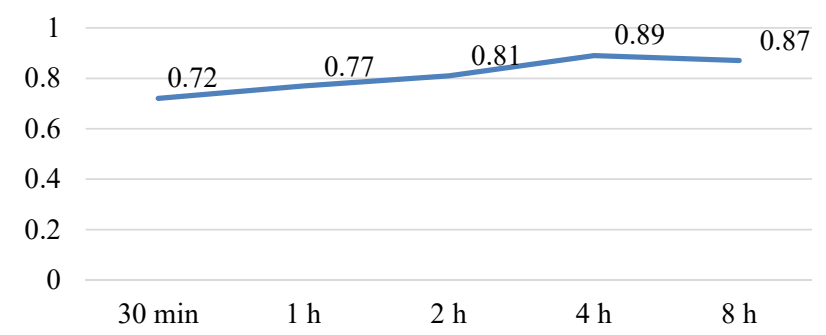

Fig. 5. The content of flavonoids in percentage depending on the extraction time

As can be seen from the obtained results, maximum extraction is observed in the mode of infusion 4 hours. The amount of flavonoids extracted during this time is $0.89 \%$, after which it begins to decrease.

The final stage of our work was the study of technological parameters of raw materials, such as the moisture content; absorption by the raw material of the extractant; specific, bulk and bulk mass, porosity and free volume of the raw material layer, the results are given in Table $\mathbf{1}$.

The absorption coefficient of the extractant characterizes the amount of solvent that fills the intercellular pores, vacuoles, air cavities in the plant material and is not removed from the meal. The absorption coefficient was calculated by the difference between the volume of the extractant, which was filled with a known sample of raw material, and the volume obtained after the discharge, squeezing the meal. The obtained value of $3.3 \mathrm{ml} / \mathrm{g}$ is quite high and needs to be taken into account when developing the method of obtaining the extract. 
Table 1

The results of determining the technological parameters of leaves of Acorus calamus

\begin{tabular}{ccc}
\hline No. & Technological parameter & Result \\
\hline 1 & The degree of grinding, $\mathrm{mm}$ & $0.5-1.0$ \\
2 & Specific gravity, $\mathrm{g} / \mathrm{cm}^{3}$ & 1.03 \\
3 & Volume weight, $\mathrm{g} / \mathrm{cm}^{3}$ & 0.24 \\
4 & Bulk weight, $\mathrm{g} / \mathrm{cm}^{3}$ & 0.10 \\
5 & Porosis & 0.685 \\
6 & Porosity & 0.74 \\
7 & Free volume of the layer & 0.92 \\
8 & Weight loss on drying, $\%$ & 9.7
\end{tabular}

\section{Discussion}

As can be seen from the results of the study, the selected conditions provide the maximum extraction of phenolic compounds. $70 \%$ ethanol was selected as the extractant, providing maximum extraction and, due to its antimicrobial properties, capable of providing high extraction stability over time. The selected grinding degree from 0.5 to $1 \mathrm{~mm}$ ensures a simple and even loading of the percolator. The extraction time is 4 hours, which allows to intensify the process of extraction of biologically active substances.

The defined conditions generally correspond to commonly used methods of obtaining extracts from medicinal plant raw materials containing phenolic compounds [22, 23]. For most raw materials, the most optimal extractant is $70 \%$ ethanol, the size of the raw material is usually 1-2 mm. Phytochemical composition and antiradical activity of methanol extract obtained from the tetraploid species Acorus calamus were also investigated. The presence of flavonoids and protoanthocyanidins was established, but the ratio of raw material to extractant, the degree of grinding of raw materials is not indicated. In addition, the use of methanol as the extractant does not allow the use of the obtained extract in the native form, since methanol is a toxic substance. Therefore, in our opinion, the use of ethanol as an extractant is more appropriate [10].

To obtain more complete data on the content of biologically active substances, additional phytochemical studies of the component composition of phenolic compounds are required at all stages of the study using thin-layer and high-performance liquid chromatography methods, since the assessment of the completeness of extraction by dry residue and the quantitative content of the amount of flavonoids. Given that Acorus calamus leaves are an ether-containing feedstock, further study of the effect of temperature on the extraction of volatile compounds and polyphenols is possible.

The presented results will be the basis for the development of a method of obtaining a liquid alcohol-water extract from the leaves of Acorus calamus. Given the results of previous studies, it is predicted that this extract will have significant anti-inflammatory and antimicrobial effects, and will have an impact on the central nervous system.

Study limitations. During the experiment, such parameters as the extraction temperature, the raw material-extractant ratio were not investigated, and no other potentially important groups of biologically active substances, such as polysaccharides and essential oil, were determined.

Prospects for further researches. Considering the situation with stocks of raw materials Acorus calamus common in the territory of Ukraine, which are constantly declining, further exploration of the aboveground part of the plant is quite promising. The leaves of the plant can be used as an additional raw material for rhizomes, and to create unique herbal remedies. 


\section{Conclusions}

The selection of optimal extraction conditions of biologically active compounds from Acorus calamus leaves was carried out. The obtained results show that in order to obtain extracts with the maximum content of biologically active substances (flavonoids), it is advisable to use raw materials with a particle size of 0.5 to $1.0 \mathrm{~mm}$, and as an extractant $70 \%$ alcohol and an extraction time of 4 hours.

The technological parameters of the raw material were also determined in accordance with the methods of SPhU.

\section{Conflict of interest}

The authors declare there is no conflict of interest.

\section{References}

[1] WHO (2004). WHO Guidelines on Safety Monitoring of Herbal Medicines in Pharmacovigilance Systems. Geneva: World Health Organization. Available at: http://apps.who.int/medicinedocs/documents/s7148e/s7148e.pdf

[2] Kulbat, K. (2016). The role of phenolic compounds in plant resistance Biotechnol Food Sci, 80 (2), 97-108

[3] Lin, D., Xiao, M., Zhao, J., Li, Z., Xing, B., Li, X. et. al. (2016). An Overview of Plant Phenolic Compounds and Their Importance in Human Nutrition and Management of Type 2 Diabetes. Molecules, 21 (10), 1374. doi: http://doi.org/10.3390/ molecules 21101374

[4] State Register of Medicines of Ukraine. Available at: http://www.drlz.com.ua/ Last accessed: 19.02.2020

[5] Wichtl, M. (2004). Herbal drugs and phytopharmaceuticals. Boca Raton: CRC Press, 115-117.

[6] Arasan, El. R., Vijayalakshmi, M., Garikapati, D. (2009). Acorus calamus linn: Chemistry and Biology. Research Journal of Pharm. and Tech, 2 (2), 39-41.

[7] Rajput, S. B., Tonge, M. B., Karuppayil, S. M. (2014). An overview on traditional uses and pharmacological profile of Acorus calamus Linn. (Sweet flag) and other Acorus species. Phytomedicine, 21 (3), 268-276. doi: http://doi.org/10.1016/ j.phymed.2013.09.020

[8] Balakumbahan, R., Rajamani, K., Kumanan, K. (2010). Acorus calamus: An overview. Journal of Medicinal Plants Research. 4 (25), 2740-2745.

[9] Yadav, D., Srivastava, S., Tripathi, Y. B. (2019). Acorus Calamus A Review. International Journal of Scientific Research in Biological Sciences, 6 (4), 62-67. doi: http://doi.org/10.26438/ijsrbs/v6i4.6267

[10] Devi, S. A., Ganjewala, D. (2011). Antioxidant Activities of Methanolic Extracts of Sweet-Flag (Acorus calamus) Leaves and Rhizomes. Journal of Herbs, Spices \& Medicinal Plants, 17 (1), 1-11. doi: http://doi.org/10.1080/10496475.2010.509659

[11] Kim, H., Han, T.-H., Lee, S.-G. (2009). Anti-inflammatory activity of a water extract of Acorus calamus L. leaves on keratinocyte HaCaT cells. Journal of Ethnopharmacology, 122 (1), 149-156. doi: http://doi.org/10.1016/j.jep.2008.12.011

[12] Venskutonis, P. R., Dagilyte, A. (2003). Composition of Essential Oil of Sweet Flag (Acorus calamusL.) Leaves at Different Growing Phases. Journal of Essential Oil Research, 15 (5), 313-318. doi: http://doi.org/10.1080/10412905.2003.96 98598

[13] Yaremenko, M. S., Gontova, T.M., Sira, L.M. (2018). About use and identification of not officinalis raw materials Acorus calamus L. Leaves. Medical and clinical chemistry, 20 (1), 105-110. doi: http://doi.org/10.11603/mcch.2410681x.2018.v0.i1.8772

[14] Yaremenko, M. S., Gontova, T. M., Kotova, E. E. (2018). Perspective for using Acorus Calamus leaves in medicine. The 9th International Conference on Pharmaceutical Sciences and Pharmacy Practice. Kaunas.

[15] Minarchenko, V. M. (2012). Resources of medicinal plants of Ukraine: differentiation, dynamics, strategy of optimization of use and preservation. Kyiv, 36.

[16] Industrial medicine technology. Electronic textbook (2010). Available at: http://ztl.nuph.edu.ua/medication/content.html

[17] Yaremenko, M. S., Hontova, T. M., Kotova, E. E. (2018). Terminy zahotivli lystia lepekhy zvychainoi (Acorus Calamus L.): inform. lyst $\mathrm{N}^{\circ}$ 367-2018. Ukrainskyi tsentr naukovoi medychnoi informatsii ta patentolitsenziinoi roboty (Ukrmedpatentinform). Kyiv, 40.

[18] Derzhavna Farmakopeia Ukrainy. Vol. 1 (2015). Kharkiv: Derzhavne pidpryiemstvo «Ukrainskyi naukovyi farmakopeinyi tsentr yak osti likarskykh zasobiv», 1128.

[19] Derzhavna Farmakopeia Ukrainy. Vol. 3 (2014). Kharkiv: Derzhavne pidpryiemstvo «Ukrainskyi naukovyi farmakopeinyi tsentr yak osti likarskykh zasobiv», 732 . 
[20] Kriukova, A., Vladymyrova, I. (2018). Determination Of Technological Parameters And Indicators Of The Quality Of New Herbal Collection. EUREKA: Health Sciences, 6, 61-68. doi: http://doi.org/10.21303/2504-5679.2018.00801

[21] Vyshnevska, L. I., Shmalko, O. O., Soldatov, D. P. (2019). Study on the development of multicomponent dry uroholum extract and its pharmaco-technological indicators. Management, Economics and Quality Assurance in Pharmacy, 2 (58), 16-21. doi: http://doi.org/10.24959/uekj.19.19

[22] Yanickaya, A. V., Mitrofanova, I. Yu., Heilik, Yu. V. (2014). Optimizaciya processa ekstragirovaniya flavonoidov iz travy melkolepestnika kanadskogo. Vestnik Volgogradskogo gosudarstvennogo medicinskogo universiteta, 2 (50), 20-23.

[23] Kutateladze, G. R., Fedoseeva, L. M. (2019). Research in the Development and Validation of the Method of Quantitative Determination of Flavonoids in the Common Sorrel Herba, Gathered in the Altai Territory. Drug development \& registration, 8 (2), 80-86. doi: http://doi.org/10.33380/2305-2066-2019-8-2-80-86

\title{
MARKETING ANALYSIS OF THE ASSORTMENT OF DRUGS FOR THE TREATMENT OF HERPES VIRAL DISEASES AT THE PHARMACEUTICAL MARKET OF UKRAINE
}

\author{
Lydmila Kienko ${ }^{1}$ \\ kienko.pharm@gmail.com \\ Vita Hrytsenko ${ }^{1}$ \\ nika.gritsenko@gmail.com \\ Larysa Iakovlieva \\ Department of Pharmacoeconomics ${ }^{2}$ \\ iakovlievalv@gmail.com \\ Larysa Bobrytska \\ lora2015dm@gmail.com \\ ${ }^{1}$ Department of Industrial Technology of Drugs \\ ${ }^{2}$ National University of Pharmacy \\ 53 Pushkinska str., Kharkiv, Ukraine, 61002
}

\footnotetext{
Abstract

Nowadays there is a tendency towards the spread of viral diseases that cause significant complications to human health. Therefore, the question of creating new drugs that have a high antiviral effect is topical.

The aim. To study the range of drugs in Ukraine for the treatment of herpes viral diseases.

Materials and methods. In the work were used the list of drugs from official sources of information, which were processed by methods of generalization, systematization, graphic, comparative and structural analysis.

Results and discussion. The marketing research of drugs for the treatment of herpes viral diseases presented at the pharmaceutical market of Ukraine has been conducted. According to the results it is found that 80 drugs for the treatment of herpes viral diseases of various dosage forms are presented in the domestic market, of which $70 \%$ - tablets; $51 \%$ - medicines produced by the industry of Ukraine; $94 \%$ - are monocomponent preparations.

Soft drugs play important role in the treatment of skin diseases because they provide a direct effect of the drugs on the pathogens, eliminate inflammatory phenomena and eliminate or reduce the symptoms of the disease. Soft dosage drugs have practically no contraindications, they can be used at any age, regardless of the presence of comorbidities.
} 